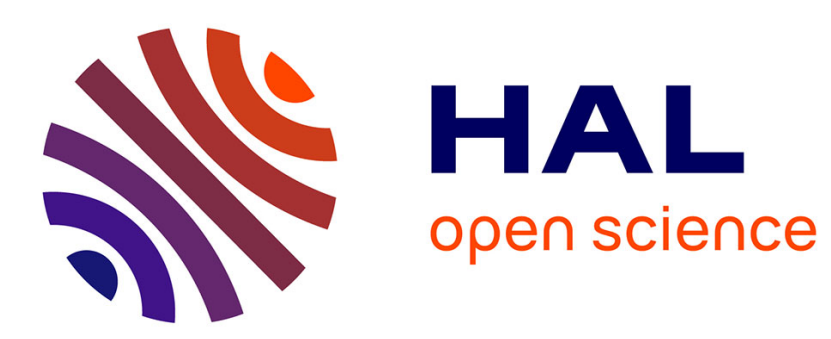

\title{
Imatinib and cardiac failure in idiopathic hypereosinophilic syndrome
}

Lisa Pieri, Alberto Bosi, Alessandro M. Vannucchi

\section{To cite this version:}

Lisa Pieri, Alberto Bosi, Alessandro M. Vannucchi. Imatinib and cardiac failure in idiopathic hypereosinophilic syndrome. Annals of Hematology, 2009, 89 (7), pp.745-746. 10.1007/s00277-009-0866-8 . hal-00535108

\section{HAL Id: hal-00535108 \\ https://hal.science/hal-00535108}

Submitted on 11 Nov 2010

HAL is a multi-disciplinary open access archive for the deposit and dissemination of scientific research documents, whether they are published or not. The documents may come from teaching and research institutions in France or abroad, or from public or private research centers.
L'archive ouverte pluridisciplinaire HAL, est destinée au dépôt et à la diffusion de documents scientifiques de niveau recherche, publiés ou non, émanant des établissements d'enseignement et de recherche français ou étrangers, des laboratoires publics ou privés. 


\title{
Imatinib and cardiac failure in idiopathic hypereosinophilic syndrome
}

\author{
Lisa Pieri • Alberto Bosi • Alessandro M. Vannucchi
}

Received: 10 November 2009 / Accepted: 13 November 2009 /Published online: 2 December 2009

(C) Springer-Verlag 2009

\section{Dear Editor,}

Idiopathic hypereosinophilic syndrome (HES) is a myeloproliferative neoplasm characterized by persistent eosinophilia due to abnormal proliferation of eosinophil precursors [1]. Tissue infiltration by eosinophils and the release of their granuli content cause organ damage. There is no specific treatment for HES; however, similar to most cases of eosinophilias harboring rearrangement of PDGFRA, some patients respond to the tyrosine kinase inhibitor Imatinib [2].

A 61-year-old female patient was referred to our institution for persistent eosinophilia $\left(3.1 \times 10^{9} / \mathrm{L}\right)$ associated with fever and recurrent pericardial and monolateral pleural effusion. A bone marrow biopsy revealed an increased number of precursor and mature eosinophils without an excess of blasts; no cytogenetic abnormality was discovered; the FIP1L1/PDGFRA rearrangement was absent, and there was no evidence of T cell clonality. An echocardiogram resulted normal except for minimal pericardial effusion. A diagnosis of idiopathic HES was made, and an effective steroid therapy was maintained until resolution of clinical signs and normalization of eosinophil count. Due to poor tolerance, corticosteroids were gradually reduced until withdrawal. After 2 months, the patient presented again with increased eosinophil count and a swelling of left arm; magnetic resonance imaging (MRI) was suggestive for muscular tissue infiltration, and a biopsy showed signs of tissue inflammation with eosinophils. Imatinib was started at a daily dose of $100 \mathrm{mg}$. Two weeks later, the left arm mass had totally resolved, but her

L. Pieri $\cdot$ A. Bosi $\cdot$ A. M. Vannucchi $(\bowtie)$

UF di Ematologia, Dip. Area Critica, University of Florence,

Florence, Italy

e-mail: amvannucchi@unifi.it absolute eosinophil count was still $3.8 \times 10^{9} / \mathrm{L}$, and progressive weakness with dyspnea and peripheral edema occurred. Imatinib was promptly discontinued, and she was admitted to the hospital. Troponin level was increased to $2.8 \mu \mathrm{g} / \mathrm{L}$, and an electrocardiogram showed an ST-T depression. A trans-thoracic echocardiogram and a cardiac MRI revealed severe increase in the thickness with hypokinesis of the left ventricle (LV) wall and partial obliteration of LV due to endoventricular thrombosis (Fig. 1).

Cardiotoxicity as an unwanted side effect of imatinib was described in an animal model and raised concern about its potential to induce cardiac heart failure (CHF) [3]. However, studies in large and rigorously monitored series of patients with chronic myelogenous leukemia and gastrointestinal tumors receiving imatinib at the usual dose of $400 \mathrm{mg} /$ day concluded that CHF is very uncommon in the absence of pre-existing cardiac defects and not dissimilar to that expected in the general population.

Infiltration of cardiac muscle and/or endoventricular thrombi can develop as part of natural history of HES, and we hypothesize that they had contributed to the rapid onset of CHF after starting low-dose imatinib. Since a routine echocardiogram performed 9 months apart was normal, we hypothesize that cardiac eosinophilic infiltration and the LV thrombosis had occurred during this lapse of time. There are a few case reports of patients affected by HES with overt cardiac involvement that manifested a rapid worsening of cardiac status after beginning imatinib therapy that was reversible after withdrawal of the drug $[4,5]$. Therefore, we suggest that careful cardiac evaluation should be performed immediately before starting imatinib treatment in any HES patient in order to exclude unidentified and clinically silent cardiac abnormalities that could be exacerbated by drug treatment. 


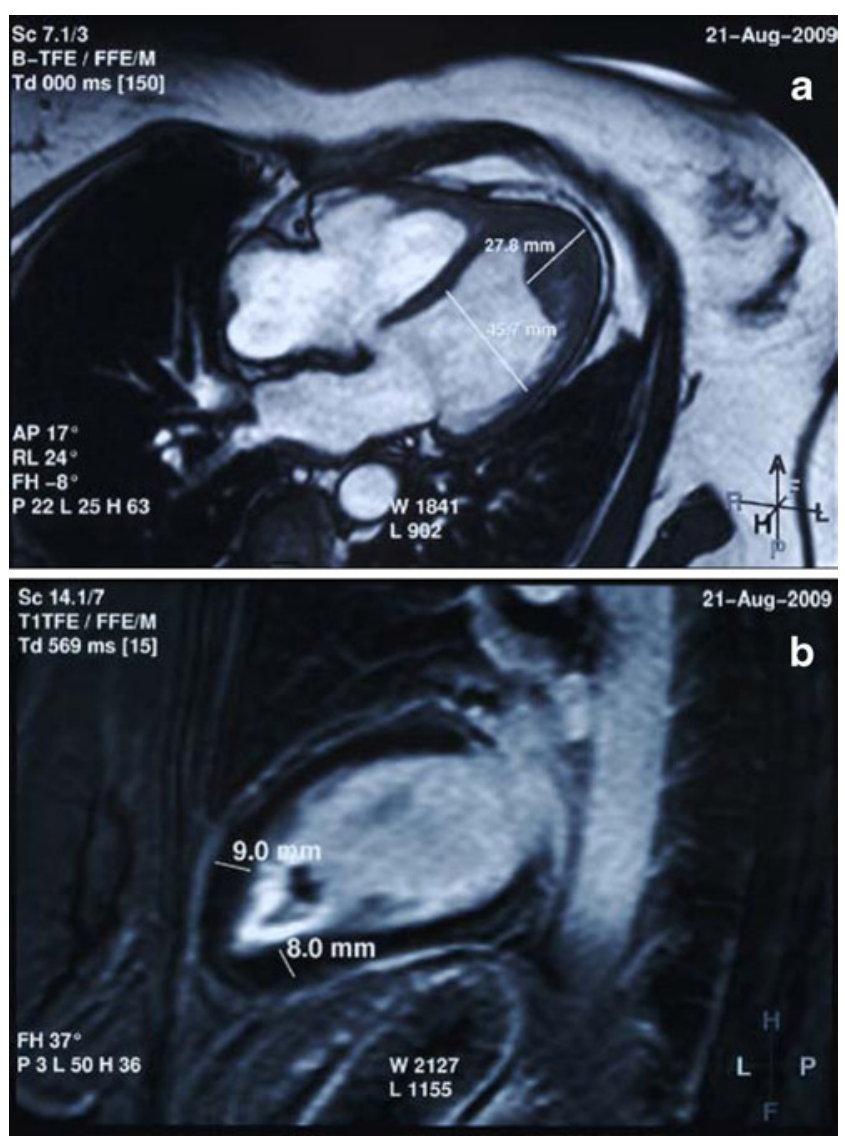

Fig. 1 Cardiac MRI study. Images demonstrated thickening of left ventricular wall (up to a maximum of $27.8 \mathrm{~mm}$ ) that showed three distinct components: an external one represented by myocardial wall appearing hypertrophic and hypokinetic, a medium one appearing as T2-hyperintense, and an internal one that resulted hypointense. The latter lacked enhancement after intravenous application of Gadovist (gadobutrol), suggestive of thrombotic material. As a whole, these images were indicative of endomyocardial fibrosis with thrombosis

\section{References}

1. Swerdlow SH, Campo E, Harris NL, Jaffe ES, Pileri SA, Stein H, Thiele J, Vardiman JW (ed) (2008) WHO classification of tumors of haematopoietic and lymphoid tissues. International Agency for Research on Cancer, Lyon

2. Intermesoli T, Delaini F, Acerboni S et al (2009) A short low-dose imatinib trial allows rapid identification of responsive patients in hypereosinophilic syndromes. Br J Haematol 147:681-685

3. Kerkela R, Grazette L, Yacobi R et al (2006) Cardiotoxicity of the cancer therapeutic agent imatinib mesylate. Nat Med 12:908-916

4. Pardanani A, Reeder T, Porrata LF, Li CY, Tazelaar HD, Baxter EJ, Witzig TE, Cross NC, Tefferi A (2003) Imatinib therapy for hypereosinophilic syndrome and other eosinophilic disorders. Blood 101(9):3391-3397

5. Garcia-Alvarez A, Sitges M, Garcia-Albeniz X, Sionis A, LomaOsorio P, Bosch X (2008) Atypical cardiac manifestation of hypereosinophilic syndrome and reversible cardiotoxicity to imatinib. Int J Cardiol Dec 2. [Epub ahead of print] 